RICYDE. Revista Internacional de Ciencias del Deporte doi: $10.5232 /$ ricyde

Rev. int. cienc. deporte

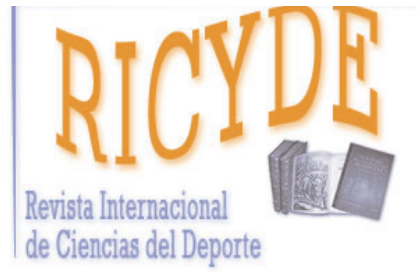

RICYDE. Revista Internacional de Ciencias del Deporte VOLUME XII - YEAR XII

Pages:5-28 ISSN:1885-3137

Issue 43 - January - 2016

\title{
The effectiveness of an Autonomy-Supportive Teaching Structure in Physical Education \\ Eficacia de la estructura de enseñanza con soporte de autonomía en educación física
}

\author{
How Yew Meng, John Wang Chee Keng \\ National Institute of Education. Nanyang Technological University. Singapore
}

\begin{abstract}
PE teachers' motivational styles have a substantial impact on students' engagement in learning and can influence children to adopt physically active lifestyles. The Self-Determination Theory (SDT) seeks to explain human motivation and behaviour. Central to SDT, three basic psychological needs must be supported (the needs for autonomy, competency and relatedness) to enhance intrinsic motivation. Autonomy-support refers to the subjective experience of autonomy. Structure is important in PE as it creates the conditions whereby effective learning can take place. The current study examined the effects of a ten-week, school-based, autonomy-supportive structure (ASTS-PE) teacher training intervention in PE, on students' PE outcomes. Psychological needs satisfaction, perceived autonomy-support, relative autonomy index (RAI), engagement and objective moderate-vigorous physical activity (MVPA) levels in PE were measured. The study consists of two treatment (autonomy-supportive structure and autonomy-support only) and one control group. The results indicate that students in the autonomy-supportive structure group show better overall outcomes compared to the other two groups. The findings in this study provide strong evidence that both autonomysupport and structure are needed to maximise effectiveness in PE lessons. We further suggest practical ways in which teachers could implement an autonomy-supportive structure in their lessons.
\end{abstract}

Key words: self-determination theory; physical activity; motivation, instructional strategies.

\section{Resumen}

Los estilos motivacionales de los profesores de educación física tienen un impacto sustancial en el compromiso de aprendizaje y pueden influir en la adopción, por parte de los niños, de un estilo de vida físicamente activo. La teoría de la autodeterminación (SDT) trata de explicar el comportamiento y la motivación humana. Según esta teoría, tres necesidades psicológicas deben ser respaldadas para potenciar la motivación intrínseca (la necesidad de autonomía, de competencia y de relación). El soporte de autonomía se refiere a la experiencia subjetiva de autonomía. La estructura en las clases de educación física es importante en cuanto a la creación de condiciones que permiten que tenga lugar un aprendizaje efectivo. El presente estudio examinó los efectos de una enseñanza con una estructura de soporte de autonomía en estudiantes de educación física tras un entrenamiento de 10 semanas. Se midieron la satisfacción de las necesidades psicológicas, el nivel de apoyo a la autonomía percibido, el índice de autonomía relativo (RAI), el compromiso y los niveles la actividad objetiva moderada-vigorosa (MVPA). El estudio consta de dos condiciones (estructura de apoyo a la autonomía y solamente soporte de autonomía) y un grupo control. Los resultados indican que los estudiantes en el grupo de estructura de apoyo a la autonomía mostraron mejores resultados globales en comparación con los otros dos grupos. Los resultados de este estudio proporcionan una fuerte evidencia de que tanto el apoyo a la autonomía y la estructura son necesarios para maximizar la eficacia en las clases de educación física. Además, sugerimos maneras prácticas en las que los profesores podrían implementar una estructura de apoyo a la autonomía en sus clases.

Palabras clave: teoría de la autodeterminación; actividad física; motivación; estrategias de instrucción.

Correspondence/correspondencia: How Yew Meng

National Institute of Education. Nanyang Technological University. Singapore

Email: yewmeng.how@gmail.com 


\section{Introduction}

$\mathrm{PE}$ teachers' behaviours, practices and motivational styles have a substantial impact on students' feelings about and engagement in learning and can influence children to adopt physically active lifestyles as adults (Sallis \& McKenzie, 1991; Wright, Patterson, \& Cardinal, 2000). Students differ in many aspects such as learning domains, learning styles, physical growth and development, as well as social and emotional development (Cohen, 1969; Grippin \& Peters, 1984; Jenkins, 1986). Hence, PE teachers are constantly exploring effective teaching strategies to meaningfully engage and motivate students. To motivate students, an effective PE teacher needs to not only be familiar with unpredictable student behaviour, but also be well aware of the challenges to meet the diverse needs of their students.

Theories of motivation and intention are at the forefront of research examining the psychological antecedents, mechanisms, and bases for intervention in exercise contexts (Buchan, Ollis, Thomas, \& Baker, 2012). The Self-Determination Theory (SDT) is prominent among these theories and has received much attention in the literature on exercise behaviour (Ryan \& Deci, 2007). The SDT (Deci \& Ryan, 1985) explains motivation and behaviour based on individual differences in motivational orientations, contextual influences, and interpersonal perceptions.

Central to SDT is the distinction between intrinsic/autonomous forms of motivation and extrinsic/controlling forms of motivation, and the notion that individuals are more likely to continually engage in behaviours that are intrinsically motivated (Deci \& Ryan, 2008). Intrinsic motivation is defined as performing an activity for the inherent satisfaction of the activity itself while extrinsic motivation refers to the motivation for performing an activity in order to attain some separable outcome. To enhance intrinsic motivation, Deci and Ryan (1985) posit that three basic psychological needs must be supported, namely the needs for autonomy, competency and relatedness. Past research conducted via SDT theory in education has examined the importance of teachers in influencing the degree of satisfaction of students' basic needs and motivations, depending on the motivational climate they generate. These studies found that when teachers' pedagogical practices and educational settings satisfied students' psychological nutriments of autonomy, competence and relatedness, students' state of motivation, achievement and well-being are enhanced (Deci, Ryan, \& Williams, 1996; Reeve, Jang, Carrell, Jeon, \& Barch, 2004).

The concept of autonomy that is central within SDT has long been recognized as a fundamental factor in the promotion of optimal motivation. When individuals feel that their opinions are valued, their feelings are taken into account, and they have the opportunity to make choices and be self-managers, autonomy is enhanced (Ryan \& Deci, 2000). Studies examining the learning environment in PE and physical activity (PA) settings found that students' perceptions of teachers' needs support positively predicted students' perceptions of needs satisfaction (Ntoumanis, 2005; Standage, Duda, \& Ntoumanis, 2003, 2005, 2006). Furthermore, school-based research has provided evidence that intrinsic motivation flourishes when students perceive that they are in an autonomy-supportive environment, where they have some level of control (Gairns, Whipp \& Jackson, 2015; Heine \& Caune, 2014; Jang, Reeve, \& Deci, 2010; Reeve, 2009). As such, when looking into PA intentions and adherence issues within PE, investigating the construct of autonomy is essential. 
SDT provides a window into understanding how teachers' motivational styles could possibly affect the learning environment that supports the satisfaction of psychological needs. The key point that repeatedly emerges in the literature is that an autonomy-supportive environment is preferable to a controlling environment in PE (Hagger, Chatzisarantis, Culverhouse, \& Biddle, 2003; Markland, 1999; Standage et al., 2006). However, there are currently no intervention studies examining the role of structure together with autonomysupport in PE. Past research (Skinner \& Belmont, 1993) conceptualize autonomy-support and structure as a comprehensive framework. Teachers provide structure by clearly communicating expectations and directions, leading instructional activities when appropriate, providing strong guidance, giving precise instructions when needed, scheduling student activities, marking the boundaries of activities and managing the transitions between them, offering task-focused and informational feedback, and providing consistency in the lesson (Brophy, 2006; Skinner \& Belmont, 1993). Structure is especially important in PE because it helps to maintain a high level of student engagement in practice (Rink, 2003). Teacherprovided structure helps students to develop perceived competence, an internal locus of control, mastery motivation rather than helplessness, self-efficacy, and an optimistic attributional style (Skinner, Furrer, Marchand, \& Kindermann, 2008). Conversely, when teachers provide too little structure, students fail to develop the prerequisite skills they need to experience engagement-fostering learning (deCharms, 1984). Jang, Reeve and Deci (2010) acknowledge that conceptual and theoretical definitions might capture only the essential elements of autonomy-support and structure.

Additionally, studies conducted on the effects autonomy-support in PE PA measurement so far have relied heavily on self-report data. Standage and Ryan (2012) posit that empirical and applied investigation is important in understanding the role of motivation and the processes that support, as oppose to forestall, high-quality motivated engagement in PA settings. A previous study by How and colleagues (2013) employing objective measures of PA via accelerometers indicate that students in autonomy-supportive $\mathrm{PE}$ environments tend to exhibit higher PA behaviour, with boys generally more active than girls. Additional objective behavioural measures such as extent of PA as a function of students' motivation via an autonomy-supportive structure might be of particular value.

In light of the current gaps in research, this study seeks to further understand the effects of autonomy-support and structure in PE, through a school-based intervention employing the use of experimental and longitudinal research design. The present study examined the effectiveness of autonomy-supportive structure compared to autonomy-support only. There were two interventions conditions: an autonomy-supportive intervention that includes the role of structure associated with PE classes and an autonomy-supportive intervention that provided rationale, feedback, choice and acknowledged difficulties only. The two interventions differ in the way that structure is used to underpin autonomy-supportive instructional behaviours in the delivery of PE lessons. Additionally, a control group was also used to compare the effects of these interventions with normal PE classes. To address the lack of objective PA data in autonomy-supportive studies, state-of the art Actigraph GT3X accelerometers was used to measure in-class PA during PE lessons. We hypothesize that students in the autonomy-supportive structure group will be more autonomously motivated, engaged and physically active than students in the autonomy-support only group. We also hypothesize that both intervention treatment groups will be more autonomously motivated, engaged and physically active than students in the control group. 


\section{Method}

\section{Participants}

The teacher participants were 8 full-time certified experienced PE teachers from 2 secondary schools in Singapore. There were 3 teachers in the control and autonomy-support only groups and 2 teachers in the autonomy-supportive structure (ASTS-PE) group. The total number of secondary school student participants was $\mathrm{N}=648$. There were 334 male and 314 female students, with mean age of 14.35. There were 236 students in the control group, 173 students in the autonomy-supportive structure group and 239 students in the autonomy-supportive only group. Teachers and classes were not selected randomly but on the basis of negotiation with the school and the teachers.

\section{Procedure}

The study consists of three experimental conditions to determine the effectiveness of autonomy-supportive teaching structure in PE in changing teachers' beliefs on motivational styles. Schools were assigned, by simple random allocation, to a control or to either of the two treatment conditions. The three conditions are: a) autonomy-supportive teaching structure, b) autonomy-supportive motivational style only, and c) control condition whereby teachers taught as per normal. The teachers in the experimental groups participated in the training intervention, whereas teachers in the control group received no training. The PE teachers' training hours in the intervention groups depended on the treatment condition. Teachers in the autonomy-support only group went through Stage 1 and 2 of the training, while the teachers in the Autonomy-Supportive Teaching Structure-PE (ASTS-PE) group went through all three stages of training, during which they had the opportunity to role-play the recommended teaching styles and be given feedback.

Following the teachers' training intervention, teachers in the experimental conditions implemented changes in their teaching style for 10 weeks during their PE lessons. The duration of the PE lessons was one hour for all classes. At pre-test, pupils in all conditions completed measures of autonomous motivation in PE, classroom engagement, perceived autonomy-support and perceived locus of causality. At post-test, we measured these student variables again in order to examine whether teachers were successful in bringing about positive student outcomes. PA level via accelerometers was measured throughout the duration of the study. To control for the levels of physical activity levels, all the teachers in the three groups were teaching territorial-invasion style games (for example games such as soccer, basketball, etc.). Additionally, teachers in the experimental conditions were given assistance and advice to develop autonomy-supportive lesson plans. However, the teachers decided the details of the lessons, such as type of activity, so that their autonomy is supported as well.

\section{Autonomy-Supportive Teaching Structure in PE Programme (ASTS-PE)}

Participation in the autonomy-supportive teaching structure in PE (ASTS-PE) constituted the study's independent variable. The training for ASTS-PE was provided in three stages. The schematic of the intervention programme is shown in Figure 1. 
Stage 1 consists of a three hour workshop. It began with a reflective warm-up activity in which teachers read two teaching scenarios, one that described highly autonomy-supportive teaching and another that described highly controlling teaching, and answered questions about how well these scenarios described their own teaching. A media-rich PowerPoint presentation followed to discuss the nature of student motivation (what it is, where it comes from), teachers' motivating styles toward students, classroom examples of autonomysupportive instruction, and empirical evidence with a group discussion about the feasibility, potential obstacles, and specific "how to" ideas related to enacting an autonomy-supportive style in the context of the Singaporean PE classroom.

Stage 2 consists of a brief PowerPoint presentation of autonomy-supportive teaching that reinforced the presentation from Stage 1 . This section was primarily focused on information and discussion, in which teachers discussed, shared, suggested, and critiqued specific approaches to instruction, usually within the context of a specific sport-based activity (e.g., during a soccer activity). A comprehensive training package on based the Five Acts of

Autonomy-Supportive Behaviour (Reeve, 2009) was provided to teachers, to help them operationalize and implement autonomy supportive lessons.

Stage 3 consisted of a group discussion that centered largely on sharing ideas in how to be autonomy-supportive as well as provide structure during PE instruction. Information would be shared on the importance of structure in PE instruction. Jang and colleagues (2010) posit that in order for a lesson to be well structured, teachers are to provide leadership in key points in the lesson. Together with the training package given in Stage 2, the teachers were also provided with a sample lesson plan to suggest how an autonomy-supportive teaching structure in PE can be operationalized. Teachers were free to change or adapt the lesson plan as they saw fit. Teachers were further encouraged to set a specific instructional goal for their PE class in terms of enacting an autonomy-supportive teaching structure (e.g., offer explanatory rationales for requests). Figure 2 shows a suggested ASTE-PE lesson plan. 
Meng, H.Y.; Keng, J.W.C. (2016). The effectiveness of an Autonomy-Supportive Teaching Structure in Physical Education. RICYDE. Revista internacional de ciencias del deporte, 43(12), 5-28. http://dx.doi.org/10.5232/ricyde2016.04301

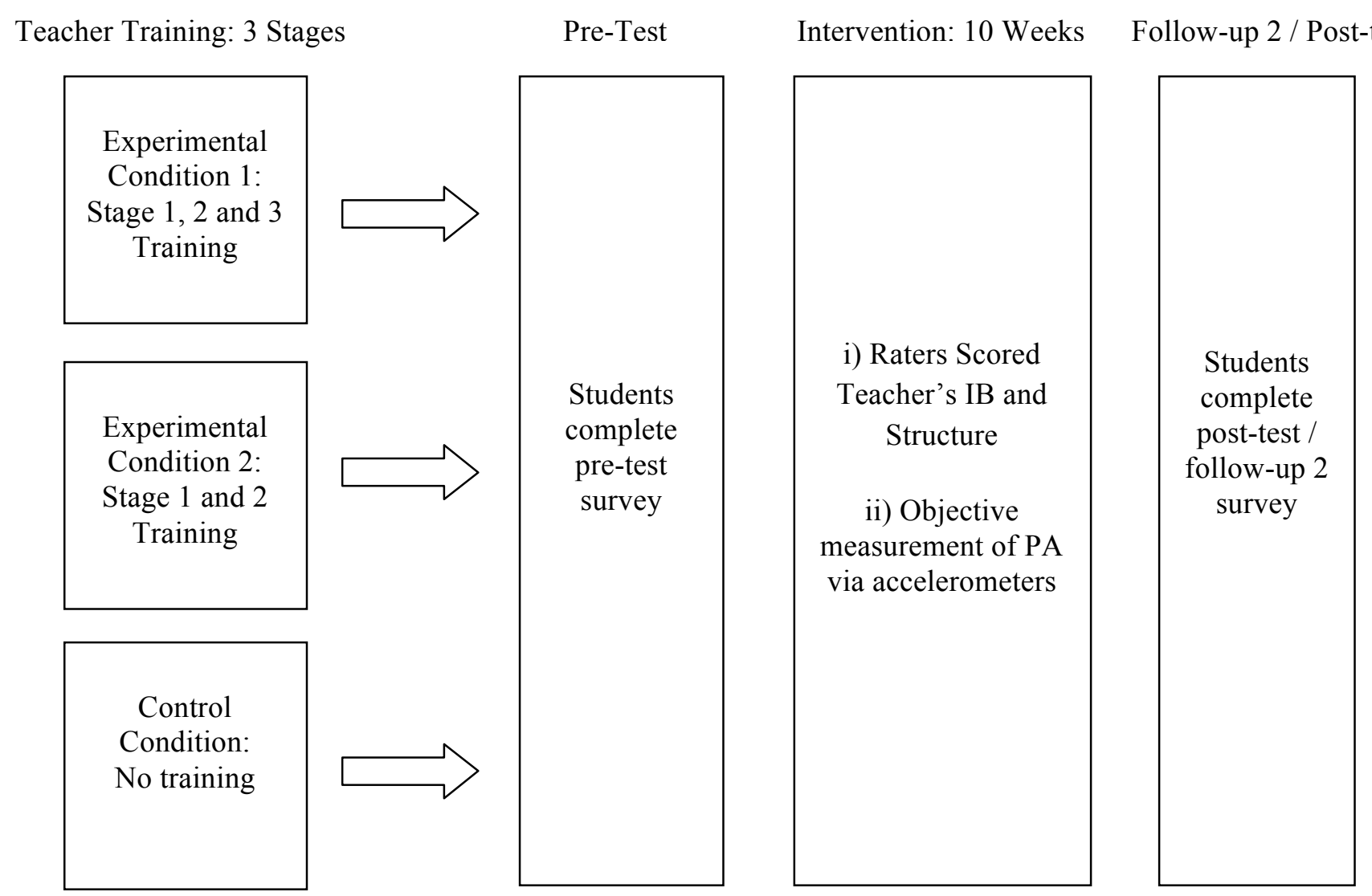

Figure 1. Research Protocol for Intervention 


\section{Manipulation check}

To also ensure that the PE teachers in the intervention groups used the instructional style that were taught, an expert in SDT observed these PE teachers in action and provided feedback about their performance. The expert helped score the PE teachers' classroom instruction in terms of autonomy-supportive and controlling teaching as well as the provision of structure. The autonomy-supportive rating sheet includes four instructional behaviors presented in a bipolar format with the autonomy-supportive behavior on the right side (scored as 7) accompanied by illustrative descriptors and the controlling behavior on the left side (scored as 1) accompanied by illustrative descriptors. This rating sheet has been used successfully in past studies (Reeve et al., 2004), and it has produced scores that were both reliable (high inter-rater reliabilities, high internal consistencies) and valid. Teachers' provision of structure were scored via the rating sheet proposed by Jang, Reeve and Deci (2010).

\section{Measures}

Basic psychological needs satisfaction. To assess autonomy need satisfaction, students completed a five-item perceived autonomy scale that has been widely used within the PE setting (Cheon \& Moon, 2010; Standage et al., 2006; Taylor \& Lonsdale, 2010; Taylor, Ntoumanis, Standage, \& Spray, 2010) . Sample items include "I have my own say regarding which skills I want to practise in this PE class" and "I can decide which activities I want to practise in this PE class". To assess competence need satisfaction, students completed the four-item perceived competence subscale from the version of the Intrinsic Motivation Inventory developed specifically for sport-based activity (McAuley, Duncan, \& Tammen, 1989). This perceived competence measure (e.g., "I think I am pretty good at PE.") has shown strong psychometric properties when applied in PE settings (Ntoumanis, 2001; Standage et al., 2006; Taylor et al., 2010). To assess relatedness needs satisfaction, students completed the four-item perceived relatedness scale that measures students' felt closeness to their classroom teacher (Furrer \& Skinner, 2003). Teacher relatedness is only one aspect of relatedness need satisfaction, as PE students also experience varying degrees of peer relatedness, but we focused only on teacher relatedness because our study was a teacher intervention. We adapted the scale for the PE classroom setting by rewording the stem "When I am with my teacher. . ."to "When I am with my PE teacher. . . ." Sample items that complete this stem include, "I feel accepted" and "I feel ignored" (reverse scored).

Motivation orientation. The 17-item Perceived Locus of Causality (PLOC) developed by Goudas, Biddle, \& Fox (1994) and cross-culturally validated in Singapore (Wang, Hagger, \& Liu, 2009) was used to measure students' behavioural regulation in PE. The PLOC consists of five subscales measuring amotivation (e.g., “...but I really don't know why”), external regulation (e.g., “...because I'll get into trouble if I don't”), introjected regulation (e.g., “...because I would feel bad about myself if I didn't"), identified regulation (e.g., "...because I want to learn sport skills"), and intrinsic regulation (e.g., "...because sport is fun"). 
Meng, H.Y.; Keng, J.W.C. (2016). The effectiveness of an Autonomy-Supportive Teaching Structure in Physical Education. RICYDE. Revista internacional de ciencias del deporte, 43(12), 5-28. http://dx.doi.org/10.5232/ricyde2016.04301

\begin{tabular}{|c|c|c|c|c|}
\hline Phases & Task & $\begin{array}{c}\text { Autonomy-supportive Structure } \\
\text { Dimension }\end{array}$ & Characteristic & Application \\
\hline \multirow{4}{*}{$\begin{array}{l}\text { Pre-Lesson } \\
\text { (Expectations) }\end{array}$} & 1) Class commence & 1) Interpersonal Involvement & $\begin{array}{l}\text { 1) Dedicate resources to students, } \\
\text { Close proximity }\end{array}$ & $\begin{array}{l}\text { 1) Learn names, spend time chatting at } \\
\text { start of class, show affection } \\
\text { /enjoyment }\end{array}$ \\
\hline & 2) Warm Up & $\begin{array}{l}\text { 2) Nurture inner motivational } \\
\text { resources; } \\
\text { Display patience for self-paced } \\
\text { learning. }\end{array}$ & $\begin{array}{l}\text { 2) Provide choice and allowance for } \\
\text { student initiation of activities }\end{array}$ & $\begin{array}{l}\text { 2) Provide options about pace, } \\
\text { frequency and type of activity and } \\
\text { where possible, allow students to self- } \\
\text { initiate warm-up }\end{array}$ \\
\hline & 3) Setting Goals & 3) Demonstrate good leadership & $\begin{array}{l}\text { 3) Discuss plans and set goals at the } \\
\text { start of the class }\end{array}$ & $\begin{array}{l}\text { 3) Frames the lesson to guide student } \\
\text { understanding }\end{array}$ \\
\hline & $\begin{array}{l}\text { 4) Explain Rationale } \\
\text { Objectives }\end{array}$ & $\begin{array}{l}\text { 4) Rely on informational language; } \\
\text { Provide explanatory rationales }\end{array}$ & 4) Provide meaningful rationale & $\begin{array}{l}\text { 4) Explain why each activity is } \\
\text { beneficial }\end{array}$ \\
\hline During- & 1) Demonstration & $\begin{array}{l}\text { 1) Demonstrate good leadership; Clear } \\
\text { instructions; Setting expectations }\end{array}$ & $\begin{array}{l}\text { 1) Demonstrations provide the model } \\
\text { and the image of the content; Set clear } \\
\text { boundaries and expectations for } \\
\text { behaviour }\end{array}$ & $\begin{array}{l}\text { 1) Clear teaching cues for content } \\
\text { replication and clarification; Allow } \\
\text { student voice / participation in setting } \\
\text { of goals/objectives }\end{array}$ \\
\hline (Scaffolding) & 2) Practice / Games & $\begin{array}{l}\text { 2) Provide choice and differentiation, } \\
\text { Foster sense of curiosity, Be } \\
\text { supportive and praise quality, Provide } \\
\text { optimal challenge }\end{array}$ & $\begin{array}{l}\text { 2) Provide strong guidance/ scaffold } \\
\text { learning via timely informational } \\
\text { feedback }\end{array}$ & $\begin{array}{l}\text { 2) Praise improvements in technique, } \\
\text { Work at a level that pushes students } \\
\text { maximally but accommodate those } \\
\text { less able }\end{array}$ \\
\hline $\begin{array}{l}\text { Post-Lesson } \\
\text { (Feedback) }\end{array}$ & $\begin{array}{l}\text { 1) Debrief/ } \\
\text { Questions/Feedback }\end{array}$ & $\begin{array}{l}\text { 1) Rely on informational language; } \\
\text { Provide explanatory rationales; } \\
\text { Interpersonal involvement }\end{array}$ & $\begin{array}{l}\text { 1) Reinforce main teaching points. } \\
\text { Maintain positive teach-student } \\
\text { relationship }\end{array}$ & $\begin{array}{l}\text { 1) Help student reflect on their } \\
\text { motivational, behavioural, and } \\
\text { performance characteristics while } \\
\text { maintaining their personal } \\
\text { responsibility for their learning. }\end{array}$ \\
\hline
\end{tabular}

Figure 2. ASTS-PE Lesson Plan 
Participants responded to all the items on a 7-point Likert scale $(1=$ "Not true at all", $7=$ "Very true"). Following the guidelines recommended by Standage and colleagues (2006), autonomous motivation was scored using the relative autonomy index (RAI) in which the four scale scores are weighted and combined into one overall score as follows: RAI $=2 \times$ intrinsic regulation $+1 \times$ identified regulation $+(-1) \times$ introjected regulation $+(-2) \times$ external regulation. The RAI score can range from -18 to 18 (from lowest to highest autonomy).

Perceived autonomy-support. The Learning Climate Questionnaire (LCQ) developed by (Williams \& Deci, 1996) was used to ascertain the degree to which the PE lessons were undertaken in an autonomy-supportive environment. This instrument consisted of two forms: (a) a longer 15-item version; and (b) a shorter 6-item version. Both versions used a 7-point Likert scale ranging from 1 (strongly disagree) to 7 (strongly agree). In this study, the shorter 6-item version instrument was used (refer to Appendix I). The short version of the LCQ has been widely used in investigations of autonomy-support (Black \& Deci, 2000; Jang, Reeve, Ryan, \& Kim, 2009). Scores were calculated by averaging the individual item scores. Higher average scores represent a higher level of perceived autonomy-support and vice-versa. We slightly modified the LCQ by changing "My teacher" to "My PE teacher" (e.g., "My PE teacher provides me with choices and options.").

Classroom engagement. Following the consensus perspective in the classroom engagement literature (Christenson, Reschly, \& Wylie, 2012; Reeve \& Tseng, 2011), we conceptualized students' classroom engagement as a multidimensional construct consisting of the four following aspects: behavioral, emotional, cognitive, and agentic. To assess behavioral engagement, we used a slightly modified version of Skinner and colleagues' (2009) five-item scale (modified for the PE classroom context) to assess extent of attention, effort, and persistence during class (e.g., "In PE class, I work as hard as I can."). To assess emotional engagement, we used a modified version of Skinner and colleagues (2009) five-item scale to assess the extent of positive emotions during PE class (e.g., "When I am in PE class, I feel good."). To assess cognitive engagement, we used a modified version of Wolters' (2004) five-item scale to assess learning strategies while trying to learn PE-related skills (e.g., "When learning a PE activity, I try to relate what I'm learning to what I already know."). To assess agentic engagement, we used a modified version of Reeve and Tseng's (2011) fiveitem scale to assess students' constructive contribution into the flow of the instruction they received (e.g., "During this class, I express my preferences and opinions."). The scores from the four scales were equally weighted and averaged into one overall classroom engagement score.

Physical activity levels. The ActiGraph GT3X (ActiGraph, LLC, Fort Walton Beach, FL) measures and records time-varying accelerations ranging in magnitude from approximately $0.05 \mathrm{~g}$ to $2.5 \mathrm{~g}$. The output of the accelerometer is provided in counts, which represent a quantitative measure of activity over time. The PA intensity level in ActiGraph GT3X accelerometers was measured using Evenson and colleagues' (2008) energy expenditure (EE) cut points: Sedentary $\leq 100$; Light PA $>100$; Moderate PA $\geq 2296$ and Vigourous PA $\geq 4012$. An evaluative study on the EE equation by Trost, Loprinzi, Moore and Pfeiffer (2011) found that the cut points by Evenson and colleagues (2008) provided acceptable classification accuracy for all four levels of PA intensity and performed well in estimating time spent in sedentary, light-, moderate-, and vigorous-intensity activity among children and adolescents. 


\section{Data Analysis}

Before conducting the main analyses, the whole data were preliminarily analyzed (i.e., outliers cleaning, univariate normality, multivariate normality, and internal reliability tests) by using SPSS 21.0. Cronbach's $a$ was used to assess reliability of the scales. Descriptive statistics and Pearson product-moment correlations of the main variables were computed.

To assess validity, CFAs were employed to test the psychometric properties of the various measures used in this study, using EQS 6.1 (Bentler \& Wu, 2002). Regarding a sample size for CFA, 100 or above is generally deemed appropriate to provide sufficient statistical power (Hoelter, 1983). Normalized estimate (Mardia, 1970) was used for examining multivariate normality of the data. In practice, values of normalized estimate higher than 3.00 provide evidence of data non-normality, and larger values are more likely to affect the modeling statistics such as the $\chi^{2}$ test in CFA (Bentler \& Wu, 2002). If the data does not not achieve multivariate normality (Mardia, 1970; Satorra \& Bentler, 1994), the robust maximum likelihood estimation procedure, also known as the Satorra-Bentler scaled chi-square ( $\mathrm{SB} \chi^{2}$; Chou \& Bentler, 1995) will be used to assess validity. To assess the global model fit, multiple fit indices were employed to evaluate the global model fit: $\mathrm{SB} \chi^{2}$ to degree of freedom ratio $\left(\mathrm{SB} \chi^{2} / d f\right)$, comparative fit index (CFI), and root mean squared error of approximation (RMSEA) with $90 \%$ confidence interval $(90 \% \mathrm{CI})$. A value of $\mathrm{SB} \chi^{2} / d f$ ratio of less than 3.0 indicates good model fit (Kline, 2005). Regarding the cut-off values of CFI, an index value of over .90 indicated adequate fit, and an index value of over .95 represented good fit (Hu \& Bentler, 1999; Marsh, Hau, \& Wen, 2004). A cut-off value greater than 95 for NFI (normed fit index) represent a good fit (Hu \& Bentler, 1999). A cut-off value smaller than .08 for RMSEA/SRMR indicated adequate fit and a cut-off value for RMSEA smaller than .06 represented good fit (Hu \& Bentler, 1999; Marsh et al., 2004).

For the main analysis, pre- and post-intervention results that were collected from the students over the 10-week period were analyzed using a 3 (groups: autonomy-supportive structure, autonomy-support only and control) by 2 (trials: pre- and post-test) repeated-measures MANOVA, to control for Type 1 errors in the analysis of multiple dependent variables. Specifically, analyses for needs satisfaction, RAI, perceived autonomy-support and engagement treated 'group' as a between subjects factor with three levels (autonomysupportive structure, autonomy-support only and control) and 'time' as a two-level withinsubjects factor (pre/post test). For objective PA data from accelerometers, the epoch length of ActiGraph GT3X accelerometers was set at a 15-second interval. Time spent in the light, moderate and vigorous activity thresholds was calculated by dividing the number of 15second epoch lengths spent in the various PA thresholds over the total duration of the PE lesson, expressed in percentage. The percentage time in moderate-vigorous intensity was summed, and means were calculated to produce moderate-vigorous PA (MVPA) data (Trost, 2007). Subsequently, the differences between treatment groups was analyzed via univariate ANOVA with simple effects follow-up. 


\section{Results}

\section{Descriptive Statistics}

The measures used showed acceptable reliability, with Cronbach's $a$ for sub-scales ranging from .68 to .92 . The Cronbach's $a$ and Pearson correlations for pre and post-test measures are presented in Table 1 . The reliability coefficients are presented diagonally in Table 1 , in paretheses. The first value represents the Cronbach's $a$ pre-test and the second value for the post-test. The Pearson correlations for the pre-test are presented below the diagonal while the values for post-test are presented above the diagonal. Self-determination theory (Deci \& Ryan, 1985) propose that various behaviours, in relation to regulatory styles or motivational orientation, can be conceptualised along a continuum ranging from high (intrinsic motivation) to low (amotivation) levels of self-determination. This pattern (with adjacent correlations being higher than those that are more distant) is illustrated in the rank order of correlations among these regulatory styles and is known as a simplex pattern (Deci \& Ryan, 1985). The correlations for the PLOC subscales for re and post-test show a strong simplex structure. The simplex pattern is also evident when comparing the subscales for the basic psychological needs satisfaction to various behaviour regulations, with higher correlations for the more autonomous regulations and decreasing towards the more controlling regulations. All measures of engagement are positively correlated to the satisfaction of psychological needs, autonomous regulations and perceived autonomy-support and negatively correlated to controlling regulations. The descriptive statistics for psychological variables and objective MVPA are shown in Tables 2 and 3 respectively.

\section{Confirmatory factor analyses for measures}

The validity of all the measures used in the study were subjected to CFA using the robust maximum likelihood estimation procedure $\left(\mathrm{SB} \chi^{2}\right)$, as the data did not satisfy multivariate normality. In the following section, we will present first the CFA data for the pre-test measures. The data for the perceived autonomy-support scale showed good fit to the measurement model, $\mathrm{SB} \chi^{2}(9)=39.64, \mathrm{SB} \chi^{2} / d f=4.40, \mathrm{CFI}=.977, \mathrm{NFI}=.970$, RMSEA $=.077,90 \%$ CI $[0.053,0.102]$. The data for the perceived locus of causality scale showed adequate fit to the measurement model, $\mathrm{SB} \chi^{2}(109)=374.67, \mathrm{SB} \chi^{2} / d f=3.43, \mathrm{CFI}=.906$, $\mathrm{NFI}=.874$, RMSEA $=.070,90 \%$ CI $[0.062,0.077]$. The data for the engagement scale showed adequate fit to the measurement model, $\mathrm{SB} \chi^{2}(164)=639.95, \mathrm{SB} \chi^{2} / d f=3.90, \mathrm{CFI}$ $=.933, \mathrm{NFI}=.912, \mathrm{RMSEA}=.071,90 \% \mathrm{CI}[0.065,0.077]$. The data for the basic psychological needs scale showed inadequate fit to the measurement model, $\operatorname{SB} \chi^{2}(62)=$ $564.96, \mathrm{SB} \chi^{2} / d f=9.11, \mathrm{CFI}=.786, \mathrm{NFI}=.768, \mathrm{RMSEA}=.119,90 \% \mathrm{CI}[0.110,0.127]$.

Next, we will present the CFA data for the post-test measures. The data for the perceived autonomy-support scale showed good fit to the measurement model, $\mathrm{SB} \chi^{2}(9)=67.39$, $\mathrm{SB} \chi^{2} / d f=7.49, \mathrm{CFI}=.961, \mathrm{NFI}=.955, \mathrm{RMSEA}=.108,90 \% \mathrm{CI}[0.084,0.132]$. The data for the perceived locus of causality scale showed adequate fit to the measurement model, $\mathrm{SB} \chi^{2}$ $(109)=374.67, \mathrm{SB} \chi^{2} / d f=3.43, \mathrm{CFI}=.906, \mathrm{NFI}=.874, \mathrm{RMSEA}=.070,90 \% \mathrm{CI}[0.062$, 0.077]. The data for the engagement scale showed adequate fit to the measurement model, $\mathrm{SB} \chi^{2}(164)=596.99, \mathrm{SB} \chi^{2} / d f=3.64, \mathrm{CFI}=.933, \mathrm{NFI}=.910, \mathrm{RMSEA}=.069,90 \% \mathrm{CI}$ $[0.063,0.075]$. The data for the basic 
Meng, H.Y.; Keng, J.W.C. (2016). The effectiveness of an Autonomy-Supportive Teaching Structure in Physical Education. RICYDE. Revista internacional de ciencias del deporte, 43(12), 5-28. http://dx.doi.org/10.5232/ricyde2016.04301

Table 1. Cronbach's Alpha and Pearson Correlation for Main Variables

\begin{tabular}{|c|c|c|c|c|c|c|c|c|c|c|c|c|c|}
\hline Measures & 1 & 2 & 3 & 4 & 5 & 6 & 7 & 8 & 9 & 10 & 11 & 12 & 13 \\
\hline 1. Autonomy & $(.81 / .86)$ & $.47^{* *}$ & $.45^{* *}$ & $-.10^{*}$ & $-.09^{*}$ & $.14^{* *}$ & $.32^{* *}$ & $.34^{* *}$ & $.59^{* *}$ & $.39^{* *}$ & $.41^{* *}$ & $.43^{* *}$ & $.56^{\star *}$ \\
\hline 2. Competency & $.35^{* *}$ & $(.79 / .79)$ & $.52^{* *}$ & $-.31^{* *}$ & $-.19^{* *}$ & $.11^{\star *}$ & $.58^{* *}$ & $.57^{* *}$ & $.48^{* *}$ & $.60^{* *}$ & $.63^{* *}$ & $.57^{* *}$ & $.48^{\star *}$ \\
\hline 3. Relatedness & $.46^{* *}$ & $.44^{* *}$ & $(.72 / .68)$ & $-.42^{* *}$ & $-.30^{* *}$ & -.01 & $.38^{* *}$ & $.43^{* *}$ & $.61^{* *}$ & $.51^{* *}$ & $.56^{* *}$ & $.52^{* *}$ & $.42^{* *}$ \\
\hline 4. Amotivation & -.06 & $-.37^{\star *}$ & $-.36^{* *}$ & $(.69 / .77)$ & $.61^{* *}$ & $.33^{* *}$ & $-.38^{* *}$ & $-.46^{* *}$ & $-.15^{* \star}$ & $-.35^{* \star}$ & $-.44^{* *}$ & $-.28^{* *}$ & -.06 \\
\hline 5. Extrinsic & -.05 & $-.21^{\star *}$ & $-.20^{* *}$ & $.55^{\star *}$ & $(.71 / .81)$ & $.53^{* *}$ & $-.09^{*}$ & $-.21^{\star \star}$ & -.07 & $-.15^{* *}$ & $-.21^{\star *}$ & $-.12^{\star \star}$ & -.01 \\
\hline 6. Introjected & $.19^{* *}$ & $.12^{\star *}$ & .06 & $.11^{* *}$ & $.39^{* *}$ & $(.72 / .71)$ & $.22^{* *}$ & $.09^{*}$ & $.20^{\star *}$ & $.18^{* *}$ & $.15^{* \star}$ & $.23^{* *}$ & $.30^{* *}$ \\
\hline 7. Identified & $.29^{* *}$ & $.53^{* *}$ & $.41^{* *}$ & $-.46^{* *}$ & $-.20^{\star *}$ & $.29^{* *}$ & $(.83 / .82)$ & $.83^{* *}$ & $.51^{* *}$ & $.73^{* *}$ & $.75^{* *}$ & $.66^{* *}$ & $.44^{* *}$ \\
\hline 8. Intrinsic & $.26^{* *}$ & $.51^{* *}$ & $.40^{* *}$ & $-.50^{\star *}$ & $-.23^{\star *}$ & $.16^{* *}$ & $.79^{* *}$ & $(.82 / .86)$ & $.51^{* *}$ & $.71^{* *}$ & $.79^{* *}$ & $.67^{* *}$ & $.43^{* \star}$ \\
\hline $\begin{array}{l}\text { 9. Autonomy- } \\
\text { Support }\end{array}$ & $.60^{* *}$ & $.39^{* *}$ & $.58^{* *}$ & $-.19^{\star *}$ & -.05 & $.19^{* *}$ & $.50^{* *}$ & $.44^{* *}$ & $(.90 / .92)$ & $.65^{* *}$ & $.64^{* *}$ & $.70^{* *}$ & $.71^{* *}$ \\
\hline $\begin{array}{l}\text { 10. Behavioural } \\
\text { Engagement }\end{array}$ & $.37^{\star *}$ & $.54^{* *}$ & $.49^{* *}$ & $-.39^{\star *}$ & $-.22^{\star *}$ & $.22^{* *}$ & $.76^{* *}$ & $.66^{* *}$ & $.58^{* *}$ & $(.88 / .88)$ & $.88^{\star *}$ & $.82^{* *}$ & $.62^{* \star}$ \\
\hline $\begin{array}{l}\text { 11. Emotional } \\
\text { Engagement }\end{array}$ & $.34^{* *}$ & $.61^{* *}$ & $.51^{\star *}$ & $-.53^{* *}$ & $-.28^{* *}$ & $.19^{* *}$ & $.82^{* *}$ & $.80^{* *}$ & $.55^{\star *}$ & $.86^{* *}$ & $(.91 / .88)$ & $.80^{* *}$ & $.55^{\star *}$ \\
\hline $\begin{array}{l}\text { 12. Cognitive } \\
\text { Engagement }\end{array}$ & $.42^{* *}$ & $.53^{* *}$ & $.45^{* *}$ & $-.34^{\star *}$ & $-.17^{\star *}$ & $.24^{* *}$ & $.69^{* *}$ & $.61^{* *}$ & $.59^{* *}$ & $.84^{* *}$ & $.79^{* *}$ & $(.89 / .89)$ & $.71^{* *}$ \\
\hline $\begin{array}{l}\text { 13. Agentic } \\
\text { Engagement }\end{array}$ & $.57^{* *}$ & $.41^{* *}$ & $.40^{* *}$ & $-.16^{* *}$ & -.03 & $.28^{* *}$ & $.45^{* *}$ & $.38^{* *}$ & $.67^{* *}$ & $.60^{* *}$ & $.51^{* *}$ & $.72^{* *}$ & $\begin{array}{r}(.89 \\
/ .90) \\
\end{array}$ \\
\hline
\end{tabular}

Note.

i. $\quad$ * Correlation is significant at the 0.05 level (2-tailed)

ii. ** Correlation is significant at the 0.01 level (2-tailed)

iii. Pearson correlations for pre-intervention measures presented below the diagonal, and correlations at post-intervention are displayed above the diagonal

iv. Alpha coefficients presented for each instrument/subscale on the diagonal in parentheses, in the form 'pre-intervention' / 'post-intervention'. 
Meng, H.Y.; Keng, J.W.C. (2016). The effectiveness of an Autonomy-Supportive Teaching Structure in Physical Education. RICYDE. Revista internacional de ciencias del deporte, 43(12), 5-28. http://dx.doi.org/10.5232/ricyde2016.04301

Table 2. Repeated-measures MANOVA for Basic Needs, RAI, Perceived Autonomy Support and Engagement.

\begin{tabular}{|c|c|c|c|c|c|c|c|c|c|c|c|c|c|}
\hline \multirow[b]{3}{*}{ Variables } & \multicolumn{4}{|c|}{ Control Group } & \multicolumn{4}{|c|}{ Autonomy-Support and Structure } & \multicolumn{4}{|c|}{ Autonomy-Support } & \multirow[t]{3}{*}{ Sig } \\
\hline & \multicolumn{2}{|c|}{ Pre } & \multicolumn{2}{|c|}{ Post } & \multicolumn{2}{|c|}{ Pre } & \multicolumn{2}{|c|}{ Post } & \multicolumn{2}{|c|}{ Pre } & \multicolumn{2}{|c|}{ Post } & \\
\hline & Mean & SD & Mean & SD & Mean & SD & Mean & SD & Mean & SD & Mean & $\mathrm{SD}$ & \\
\hline Autonomy & 3.70 & 0.93 & 3.51 & 1.05 & 3.47 & 1.14 & 3.73 & 1.24 & 3.43 & 1.10 & 3.84 & 1.17 & $* \mathbf{T} / * \mathbf{I}$ \\
\hline Competence & 4.82 & 1.13 & 4.59 & 1.12 & 4.24 & 1.19 & 4.67 & 1.27 & 4.45 & 1.25 & 4.46 & 1.20 & $* \mathbf{I}$ \\
\hline Relatedness & 5.24 & 1.02 & 4.95 & 1.01 & 4.62 & 1.02 & 4.71 & 0.99 & 4.69 & 1.12 & 4.46 & 1.20 & $* \mathbf{T} / * \mathbf{I} / * \mathbf{G}$ \\
\hline RAI & 6.30 & 4.18 & 5.44 & 4.96 & 3.84 & 6.00 & 6.34 & 5.81 & 5.66 & 5.50 & 4.74 & 5.65 & $* \mathbf{I}$ \\
\hline Autonomy-Support & 4.63 & 1.25 & 4.41 & 1.21 & 3.98 & 1.21 & 4.23 & 1.40 & 4.06 & 1.26 & 4.05 & 1.26 & $* \mathbf{I} / * \mathbf{G}$ \\
\hline Engagement & 4.74 & 1.15 & 4.60 & 1.11 & 4.16 & 1.18 & 4.47 & 1.30 & 4.32 & 1.16 & 4.35 & 1.18 & $* \mathbf{I} / * \mathbf{G}$ \\
\hline
\end{tabular}

* $\mathrm{T}=$ Significant within group difference.

$* I=$ Significant interaction effect.

${ }^{*} \mathrm{G}=$ Significant between group difference. 
Meng, H.Y.; Keng, J.W.C. (2016). The effectiveness of an Autonomy-Supportive Teaching Structure in Physical Education. RICYDE. Revista internacional de ciencias del deporte, 43(12), 5-28. http://dx.doi.org/10.5232/ricyde2016.04301

Table 3. Effects for Percentage time in Moderate-Vigorous Intensity (MVPA) between different PE treatment conditions and gender.

\begin{tabular}{|c|c|c|c|c|c|c|c|c|}
\hline Treatment & Gender & Mean \% & SD & $\mathrm{N}$ & \multicolumn{4}{|c|}{ Post Hoc Mean Difference Comparisons (Bonferroni) } \\
\hline Control & $\begin{array}{l}\text { Girls } \\
\text { Boys } \\
\text { Overall }\end{array}$ & $\begin{array}{l}27.61 \\
30.93 \\
29.32\end{array}$ & $\begin{array}{l}9.75 \\
8.36 \\
9.15\end{array}$ & $\begin{array}{l}34 \\
36 \\
70\end{array}$ & $\begin{array}{l}\text { ASST } \\
\text { AS }\end{array}$ & $\begin{array}{l}\text { Girls } \\
-4.53 \\
2.36\end{array}$ & $\begin{array}{l}\text { Boys } \\
-11.86^{* *} \\
-3.82\end{array}$ & $\begin{array}{l}\text { Overall } \\
-8.19 * \\
-.73\end{array}$ \\
\hline $\begin{array}{l}\text { Autonomy-Support and Structure } \\
\text { (ASTS-PE) }\end{array}$ & $\begin{array}{l}\text { Girls } \\
\text { Boys } \\
\text { Overall }\end{array}$ & $\begin{array}{l}32.14 \\
42.79 \\
37.47\end{array}$ & $\begin{array}{l}8.36 \\
8.76 \\
10.05\end{array}$ & $\begin{array}{l}30 \\
30 \\
60\end{array}$ & $\begin{array}{l}\text { Control } \\
\text { AS }\end{array}$ & $\begin{array}{l}4.53 \\
6.89 *\end{array}$ & $\begin{array}{l}11.86 * * \\
8.03 * *\end{array}$ & $\begin{array}{l}8.19 * \\
7.46^{*}\end{array}$ \\
\hline Autonomy-support only (AS) & $\begin{array}{l}\text { Girls } \\
\text { Boys } \\
\text { Overall }\end{array}$ & $\begin{array}{l}25.28 \\
34.76 \\
30.00\end{array}$ & $\begin{array}{l}9.98 \\
9.37 \\
10.73\end{array}$ & $\begin{array}{l}30 \\
30 \\
60\end{array}$ & $\begin{array}{l}\text { Control } \\
\text { ASST }\end{array}$ & $\begin{array}{l}-2.36 \\
-6.89^{*}\end{array}$ & $\begin{array}{l}3.82 \\
-8.03 * *\end{array}$ & $\begin{array}{l}.73 \\
-7.46^{*}\end{array}$ \\
\hline
\end{tabular}

$*$ Difference significant at $\mathrm{p}<.05$.

** Difference significant at $\mathrm{p}<.01$. 
psychological needs scale showed inadequate fit to the measurement model, $\mathrm{SB} \chi^{2}(62)=$ $462.45, \mathrm{SB} \chi^{2} / d f=7.46, \mathrm{CFI}=.847, \mathrm{NFI}=.828, \mathrm{RMSEA}=.109,90 \% \mathrm{CI}[0.100,0.118]$.

\section{Psychological Variables}

The repeated measures MANOVA for perceived autonomy-support, basic needs, RAI and engagement showed significant group differences, Wilk's $\Lambda=.897, \mathrm{~F}(12,822)=3.83, \mathrm{p}<.01$, $\eta^{2} \mathrm{p}=.05$, significant within group differences, Wilk's $\Lambda=.938, F(6,411)=4.52, p<.01, \eta$ $2_{p}=.06$ and significant interaction effect, Wilk's $\Lambda=.838, F(12,822)=6.32, p<.01, \eta^{2} p=$ .08. Follow-up univariate ANOVAs for basic psychological needs revealed that autonomy need satisfaction showed significant within-group $(\mathrm{F}(1,416)=7.32, \mathrm{p}<.01)$ and interaction $(\mathrm{F}(2,416)=7.47, \mathrm{p}<.01)$ effects, competence need satisfaction showed significant interaction effects $(\mathrm{F}(2,416)=6.97, \mathrm{p}<.01)$ and relatedness showed significant within $(\mathrm{F}(1,416)=7.29, \mathrm{p}$ $<.01) /$ between group $(\mathrm{F}(2,416)=13.58, \mathrm{p}<.01)$ and interaction effects $(\mathrm{F}(2,416)=4.44$, $\mathrm{p}<.05)$. Follow-up univariate ANOVA for RAI showed significant interaction effects $(\mathrm{F}(2,416)=20.52, \mathrm{p}<.01)$. Perceived autonomy-support showed significant between-group $(\mathrm{F}(2,416)=7.91, \mathrm{p}<.01)$ and interaction $(\mathrm{F}(2,416)=5.25, \mathrm{p}<.01)$ effects. Finally, follow-up univariate ANOVAs for the engagement measure showed significant between group $(\mathrm{F}(2,416)=4.91, \mathrm{p}<.01)$ and interaction $(\mathrm{F}(2,416)=7.09, \mathrm{p}<.01)$ effects. Table 2 shows the results and the relevant descriptive statistics.

\section{Physical Activity levels}

For in-class PA levels, a two-way ANOVA was conducted with the three treatment conditions and gender as independent factors and MVPA as the dependent variable. Analyses revealed a significant main effect for treatment $\left(\mathrm{F}(2,184)=15.36, \eta^{2} \mathrm{p}=.14, p<.001\right)$ and gender $\left(\mathrm{F}(1,184)=34.85, \eta^{2} \mathrm{p}=.16, p<.001\right)$, with male students significantly more active than female students on average, as well as a significant interaction effect $(\mathrm{F}(2,184)=2.96, \eta$ $2 \mathrm{p}=.03, p<.05)$, indicating that treatment effects varied as a function of gender. A simple effects follow-up revealed that male students $\left(\mathrm{F}(2,93)=15.13, \eta_{\mathrm{p}}^{2}=.25, p<.001\right)$ taught with the autonomy-supportive structure were more physically active than control and autonomy-supported only male students (both $p<.01)$. Female students $\left(\mathrm{F}(2,91)=4.17, \eta^{2} \mathrm{p}\right.$ $=.08, p<.05)$ in the autonomy-supportive structure condition were also more physically active than autonomy-supported only female students $(p<.05)$. However, there was no difference for MVPA for female students who were in the autonomy-supportive structure and control conditions. These results are presented in more detail in Table 3. 


\section{Discussion}

In the present study, we manipulated the provision of autonomy-support and structure in order to understand its effects on students' participation in a 10-week period of PE. In the first phase, training for the teachers in the two experimental groups (autonomy-support only and autonomy-support and structure) was provided in three stages. In the second phase, the effectiveness of the teacher training was measured via student outcomes. Analyses indicated that students in the ASTS-PE group were more aligned with higher fulfillment of basic psychological needs, higher motivation, higher perceptions of autonomy support, higher engagement and were more active during PE.

The enhanced perception of needs satisfaction in the ASTS-PE condition is consistent with tenets of SDT concerning the nature of autonomous inter-personal styles and environments. The results of the present study indicated that students reported enhanced perceptions of autonomy support when they were taught by PE teachers who communicated rationale and feedback autonomously vis-a' -vis acknowledged personal feelings and perspectives through a consistent structure. The timely competence-relevant feedback reinforces the meaningfulness of activities by providing a reference for the students with regards to how they are performing in relation to the lesson objectives. When teachers support students' autonomy in classroom learning, such engagement provides students with information about teachers' commitment to students' well-being. These perceptions may relate to students' fulfillment of need for relatedness, leading to the significant increase in mean scores for relatedness from pre- to post-intervention in the ASTS-PE condition.

Within the SDT framework, it is posited that students who were taught by autonomysupportive teachers were more likely to report autonomous motivational styles (higher RAI) (Hagger et al., 2003; Reeve \& Jang, 2006; Ryan \& Deci, 2000). The result from this study is consistent with literature and provides additional initial evidence that when structure is provided in an autonomy-supportive way, it will be successful in enhancing students' autonomous motivational orientation. One plausible reason is that ASTS-PE provided students with the freedom and space to self-regulate their behaviour in accordance to their feelings and thoughts of the task, but at the same in a manner that is consistent and integrated with the learning objectives and goals scaffolded and guided by structure.

In the ASTS-PE condition, the findings also indicate that students in the autonomysupportive structure group showed the highest engagement, as compared to the other two experimental conditions. The results from this study provide strong substantiation that structure needs to be offered in autonomy- supportive ways if they are to support students' engagement (Jang, Reeve \& Deci, 2010). Possibly, when structure in PE is provided to students in an autonomy-supportive way, students could feel more engaged in the lesson as it enhances their self-determined learning behaviour, positive affect, deeper processing of information, and initiative towards their own learning and development.

A further aim of this study was to investigate the effects of autonomy-supportive structure on students' PA levels in PE. According to Deci and Ryan (1985), a higher level of autonomous motivation promotes increased effortful self-determined behaviour. Therefore, in the context of this study, it was hypothesized that an increase in self-determined behaviour would serve to increase students' PA levels. The results show that the autonomy-supportive structure condition reported the highest MVPA differences as compared to the autonomy-support only and control groups. Additionally, the results indicated that male students were generally more active and engaged in the greatest levels of in-class MVPA. In this study, the objective MVPA measurement was done on territorial-invasion type games that generally require 
students to participate in teams. This is done in order to delimit the confounding factors of measuring and comparing different types activities in PE. Gillison, Osborn, Standage, and Skevington (2009) discovered that sport and exercise played very different roles in the lives of adolescent boys than of girls and that they are motivated differently. In this study, the focus was largely on team games. This may have accounted for the higher MVPA for the boys as compared to the girls. Bearing in mind that boys and girls are motivated differently, it may be worthwhile for future studies to examine the effects of various types of activities on girls' MVPA behaviour in PE lessons.

\section{Practical Implications}

In light of the present findings, in order for PE to provide an effective avenue for PA participation and improve autonomous motivation among children and adolescents, educational practices that incorporate autonomy-supportive structure may be an important pedagogical consideration. In this study, we have defined the key points in a PE lesson as: a) pre-lesson, b) during-lesson and; c) post-lesson. In the following sections, we shall highlight what are some of key elements of an autonomy-supportive PE structure, and suggest ways as to how an autonomy-supportive structure may be operationalized in a PE class.

Firstly, the key element of teacher leadership in pre-lesson considerations is the setting of expectations. At the beginning of a unit or module of activity, the PE teacher may want to discuss with their students what are some of the plans, goals and standards for that unit / module and invite student responses on what they see are the possible challenges and difficulties expected from the students' perspective. The teacher may also share with the students the possible schedule of events and the rationale and perhaps elicit student feedback and suggestions on the types of activities planned. At the start of specific lessons in the unit / module, PE teachers could again reinforce the goals, rationales, objectives and expectations for the unit / module and further allow students to provide feedback where appropriate. When students have a say in the setting of expectations, it is more likely that they would abide by it.

Secondly, the key consideration for teacher leadership the during-lesson phase is scaffolding. Demonstrations and modeling of skills and techniques is especially important in PE lessons and it is necessary for teachers to demonstrate strong leadership during these lesson segments. As such, the PE teacher could come up with some rules and expectations for behaviour and consequences for non-compliance, with inputs from students. Teachers could also structure differentiated activities for optimal challenge so that students are meaningfully engaged. Additionally, teachers should employ the use of clear instructions and consistent guiding feedback during the lesson to let students know if they are on the right track and to set the boundaries. However, the students should have room and space within these boundaries to exhibit autonomously self-determined behaviour. This also ties in with providing timely and informational feedback during student practice in PE. When positive results do occur, it is critical that feedback is provided in a timely manner and that the student perceives that she or he had a direct impact on the desirable outcome through feedback. For example, the PE teacher may say that the focus of a three-versus-three soccer game should be on passing. However, the manner of passing will be free for the students to decide. If one of the students starts to dribble the soccer ball, the teacher could provide feedback to remind the student of the focus of the lesson. 
Finally, the key element for teacher leadership for the post-lesson phase of the PE lesson should be on feedback. PE teachers can influence perceptions of connectedness in PE through the type of learning climate they establish daily interactions and communication via feedback. Feelings of competence can be enhanced or negated by episodes of feedback. If an individual experiences negative feedback as calculating, in an attempt to manipulate performance, intrinsic motivation will often decrease (Deci \& Ryan, 2000). If the individual senses that the feedback is intended to be instructive and helpful, then the advice is likely to promote intrinsic motivation (Bryan \& Solmon, 2007). Worst of all, the feedback may be amotivational in nature, promoting a sense of incompetence or helplessness (Deci \& Ryan, 1985). An example of the feedback provided post-lesson, could consist of post-task analysis for the class as whole and highlight good performances of skill and technique. The PE teacher could also further engage the class and promote self-reflection via eliciting collective responses from the class as to their strengths and weaknesses for the lesson and how they would like to improve on the subsequent lessons. This gives the students a voice in contributing to their own development and learning.

\section{Limitations}

Despite enabling us to maximize external validity, the key challenge to this study was measuring students' PE outcomes in authentic, real-world conditions. Arising from this challenge were three limitations. Firstly, one limitation was that while the sample size for the study was adequately large, they came from only two schools. Although the two schools are government-funded funded public schools, generalizability of the results should proceed with caution. Secondly, the study did not measure the effects of the autonomy-supportive intervention-training programme on PE teachers due to small sample size of eight teachers. An understanding of the effects of teacher training will enable us to know how and why exactly teacher training is effective. Finally, there was the probable existence of bottom-up effects not measured or accounted for in this study. It is plausible that students' contextual responses may have been somewhat more stable than their situational motivational perceptions, and may have been less susceptible to change through manipulation. This methodological consideration may have prevented us from detecting significant effects between the autonomy-support only group and control groups in terms of autonomous motivation, as we were unable to identify whether there were any motivational changes occurring at the situational (i.e., PE lesson) level.

\section{Future Directions}

The findings of this study support the need for future research in the area of autonomysupportive structure in PE. As previously reported (Ward, Wilkinson, Graser \& Prusak, 2008), this study confirms the need for research to determine the influence of gender differences in relation to choice in PE, as well as the various motivational determinants of PA in PE. Future research might also focus on expanding the sample size of the current study to include more schools over a wider geographic and demographic area. Besides these considerations, it is also worthwhile to examine the influence of autonomy-supportive teacher training on changing teachers' motivational beliefs, as it allows us to understand whether the effects of training programmes are long-lasting or only skin-deep. This area of study may prove particularly useful given the established link between teachers' pedagogical practices and student motivation, achievement, and well-being (Alfi, Assor, \& Katz, 2004; Assor, Kaplan, \& Roth, 2002; Connell, Spencer, \& Aber, 1994; Reeve et al., 2004). 


\section{Conclusion}

One of the key goals of PE is to provide students with a supportive and highly active environment, which also facilitates the skills, knowledge, and attitudes that are necessary pursue an active, healthy lifestyle beyond the school environment. The findings highlight the importance of providing structure in autonomy-supportive training programmes in PE. Without proper structures in place to scaffold an autonomy-supportive PE lesson, there could be the possibility that the PE lesson could have come across to the students as chaotic, poorly planned and the activities conducted, laissez-faire. To our knowledge, this study is the first intervention study to date examining the relationship between autonomy-support and structure and provides strong evidence for elements of structure to be made explicit in autonomy-supportive training programmes for $\mathrm{PE}$ teachers. These findings are also noteworthy due to the relative lack of autonomous motivation that was reported by students within the control condition. In particular, teachers in control classes did not alter their 'normal' teaching and instructional behaviors, and our findings indicate that in this respect, 'normal' instructional practices may be failing, to an extent, in terms of provision of autonomous motivation. This is particularly noteworthy in light of recent findings of students' declining motivation for PE (Yli-Piipari, Wang, Jaakkola, \& Liukkonen, 2012) and our findings for this study for the Singapore youths seems to support this trend. Thus, it would appear that including specific, intentional efforts not only to provide autonomysupport, as well as to do so in a structured and consistent manner, would be sound pedagogical practice. 


\section{References}

Alfi, O.; Assor, A., \& Katz, I. (2004). Learning to allow temporary failure: Potential benefits, supportive practices and teacher concerns. Journal of Education for Teaching, 30, 27-41.

http://dx.doi.org/10.1080/0260747032000162299

Assor, A.; Kaplan, H., \& Roth, G. (2002). Choice is good, but relevance is excellent: Autonomy-enhancing and suppressing teacher behaviours predicting students' engagement in schoolwork. British Journal of Educational Psychology, 72, 261-278. http://dx.doi.org/10.1348/000709902158883

Bentler, P. M., \& Wu, E. J. C. (2002). EQS 6 for Windows: User's guide. Encino, CA: Multivariate Software.

Biddle, S.J.H. (1999). Motivation and perceptions of control: Tracing its development and plots its future in exercise and sport psychology. Journal of Sport and Exercise Psychology, 21, 1-23.

Black, A. E., \& Deci, E. L. (2000). The effects of instructors' autonomy support and students' autonomous motivation on learning organic chemistry: A self-determination theory perspective. Science Education, 84, 740-756.

http://dx.doi.org/10.1002/1098-237X(200011)84:6<740: :AID-SCE4>3.0.CO;2-3

Brophy, J. (2006). Observational research on generic aspects of classroom teaching. In $P$. A. Alexander \& P. H. Winne (Eds.), Handbook of educational psychology (2nd ed., pp. 755-780). Mahwah, NJ: Erlbaum.

Bryan, C. L., \& Solmon, M. A. (2007). Self-determination in physical education: Designing class environments to promote active lifestyles. Journal of Teaching in Physical Education, 26, 260-278.

Buchan, D.S.; Ollis, S.; Thomas, N., \& Baker, J.S. (2012). Physical Activity Behaviour: An Overview of Current and Emergent Theoretical Practices. Journal of Obesity, 1-11. http://dx.doi.org/10.1155/2012/546459

Cheon, S. H., \& Moon, I.S. (2010). Implementing an autonomy-supportive fitness program to facilitate students' autonomy and engagement. Korean Journal of Sport Psychology, 21, 175-195.

Chou, C. P., \& Bentler, P. M. (1995). Estimates and tests in structural equation modeling. In R. H. Hoyle (Ed.), Structural equation modeling (pp. 37-55). Thousand Oaks, CA: Sage.

Christenson, S.L.; Reschly, A.L., \& Wylie, C. (2012). The handbook of research on student engagement. New York: Springer. http://dx.doi.org/10.1007/978-1-4614-2018-7

Cohen, R. (1969). Conceptual Styles, Culture Conflict and Nonverbal Tests of Intelligence. American Anthropologist., 71, 828-856. http://dx.doi.org/10.1525/aa.1969.71.5.02a00040

Connell, J. P.; Spencer, M. B., \& Aber, J. L. . (1994). Educational risk and resilience in African American youth: Context, self, and action outcomes in school. Child Development, 65(493-506). http://dx.doi.org/10.2307/1131398

deCharms, R. (1984). Motivation enhancement in educational settings. In R. Ames \& C. Ames (Eds.), Research on motivation in education: Student motivation (Vol. 1, pp. 275-310). Orlando, FL: Academic Press. 
Deci, E. L., \& Ryan, R. M. (2008). Self-determination theory: A macrotheory of human motivation, development, and health. Canadian Psychology/Psychologie Canadienne, $49,182-185$.

http://dx.doi.org/10.1037/a0012801

Deci, E. L.; Ryan, R. M., \& Williams, G. C. (1996). Need satisfaction and the selfregulation of learning. Learning and Individual Differences, 8, 165-183. http://dx.doi.org/10.1016/S1041-6080(96)90013-8

Deci, E.L., \& Ryan, R.M. (1985). Intrinsic motivation and self-determination in human behavior (2nd ed.). New York: Plenum Press. http://dx.doi.org/10.1007/978-1-4899-2271-7

Evenson, K.R.; Cattellier, D.; Gill, K.; Ondrak, K., \& McMurray, R.G.(2008). Calibration of two objective measures of physical activity for children. Journal of Sports Science, 26, 1557-1565.

http://dx.doi.org/10.1080/02640410802334196

Furrer, C., \& Skinner, E. A. . (2003). Sense of relatedness as a factor in children's academic engagement and performance. Journal of Educational Psychology, 95, 148162. http://dx.doi.org/10.1037/0022-0663.95.1.148

Gairns, F.; Whipp, P.R., \& Jackson, B. (2015) Relational perceptions in high school physical education: teacher- and peer-related predictors of female students' motivation, behavioral engagement, and social anxiety. Frontiers in Psychology, 6, 113. http://dx.doi.org/10.3389/fpsyg.2015.00850

Gillison, F.; Osborn, M.; Standage, M., \& Skevington, S. (2009). Exploring the experience of introjected regulation for exercise across gender in adolescence. Psychology of Sport and Exercise, 10, 309-319. http://dx.doi.org/10.1016/j.psychsport.2008.10.004

Goudas, M.; Biddle, S.J.H., \& Fox, K.R. (1994). Perceived locus of causality, goal orientations, and perceived competence in school physical education classes. British Journal of Educational Psychology, 64, 453-563. http://dx.doi.org/10.1111/j.2044-8279.1994.tb01116.x

Grippin, P. \&, \& Peters, S. (1984). Learning Theory and Learning Outcomes: The Connection. New York: University Press of America.

Hagger, M.S.; Chatzisarantis, N.L.D.; Culverhouse, T., \& Biddle, S.J.H. (2003). The processes by which perceived autonomy support in physical education promotes leisuretime physical activity intentions and behavior: A trans-contextual model. Journal of Educational Psychology, 95, 784-795. http://dx.doi.org/10.1037/0022-0663.95.4.784

Heine, V., Caune, A. (2014). Relationships between perceived teacher's autonomy support, effort and physical self-esteem. Kinesiology, 46, 218-226.

Hoelter, D. R. (1983). The analysis of covariance structures: Goodness-of-fit indices. Sociological Methods and Research, 11, 325 - 344. http://dx.doi.org/10.1177/0049124183011003003

How, Y.M.; Whipp, P.; Dimmock, J., \& Jackson, B. . (2013). The effects of choice on autonomous motivation, perceived autonomy support, and physical activity levels in high school physical education. Journal of Teaching in Physical Education, 32, 131148.

Hu, L. , \& Bentler, P. M. (1999). Cutoff criteria for fit Indexes in covariancestructure analysis: Conventional criteria versus new alternatives. Structural Equation Modeling, 6, 1-55.

http://dx.doi.org/10.1080/10705519909540118 
Jang, H.; Reeve, J., \& Deci, E.L. (2010). Engaging students in learning activities: It is not autonomy support or structure but autonomy support and structure. Journal of Educational Psychology, 102, 588-600. http://dx.doi.org/10.1037/a0019682

Jang, H.; Reeve, J.; Ryan, R. M., \& Kim, A. (2009). Can self-determination theory explain what underlies the productive, satisfying learning experiences of collectivistically oriented Korean adolescents? Journal of Educational Psychology, 101, 644-661. http://dx.doi.org/10.1037/a0014241

Jenkins, C.P. (1986). Brain Research Leads to New Teaching Methods. BYU Today, 40, 45.

Kline, R. B. (2005). Principles and practice of structural equation modeling ( ${ }^{\text {nd }}$ ed.). New York, NY, United States: The Guilford Press.

Mardia, K.V. (1970). Measures of multivariate skewness and kurtosis with applications. Bimetrika, 57, 519 - 530.

http://dx.doi.org/10.1093/biomet/57.3.519

Markland, D. (1999). Self-determination moderates the effects of perceived competence on intrinsic motivation in an exercise setting. Journal of Sport and Exercise Psychology, 21, 351-361.

Marsh, H.W.; Hau, K-T., \& Wen, Z. (2004). In search of golden rules: Comment on hypothesis-testing approaches to setting cutoff values for fit indexes and dangers in overgeneralizing Hu and Bentler's (1999) findings. Structural Equation Modeling: A Multidisciplinary Journal, 11, 320-341. http://dx.doi.org/10.1207/s15328007sem1103_2

McAuley, E.; Duncan, T., \& Tammen, V.V. (1989). Psycho- metric properties of the intrinsic motivation inventory in a competitive sport setting: A confirmatory factor analysis. Research Quarterly for Exercise and Sport, 60, 48-58.

http://dx.doi.org/10.1080/02701367.1989.10607413

Ntoumanis, N. (2001). A self-determination approach to the understanding of motivation in physical education. British Journal of Educational Psychology, 71, 225-242. http://dx.doi.org/10.1348/000709901158497

Ntoumanis, N. (2005). A prospective study of participation in optional school physical education using a self-determination theory framework. Journal of Educational Psychology, 97, 444-453.

http://dx.doi.org/10.1037/0022-0663.97.3.444

Reeve, J. (2009). Why teachers adopt a controlling motivating style toward students and how they can become more autonomy supportive. Educational Psychologist, 44, 159175.

http://dx.doi.org/10.1080/00461520903028990

Reeve, J., \& Jang, H. (2006). What teachers say and do to support students' autonomy during a learning activity. Journal of Educational Psychology, 98, 209-218. http://dx.doi.org/10.1037/0022-0663.98.1.209

Reeve, J.; Jang, H.; Carrell, D.; Jeon, S., \& Barch, J. . (2004). Enhancing students' motivation by increasing teachers' autonomy support. Motivation and Emotion, 28, 147-169. http://dx.doi.org/10.1023/B:MOEM.0000032312.95499.6f

Reeve, J., \& Tseng, C. (2011). Agency as a fourth aspect of students' engagement during learning activities. Contemporary Educational Psychology, 36, 257-267.

http://dx.doi.org/10.1016/j.cedpsych.2011.05.002 
Rink, J.E. (2003). Effective instruction in physical education. In S. J. Silverman \& C. D. Ennis (Eds.), Student learning in physical education: Applying research to enhance instruction (pp. 165-186). Champaign, IL: Human Kinetics.

Ryan, R. M., \& Deci, E. L. (2000). Self-determination theory and the facilitation of intrinsic motivation, social development, and well-being. American Psychologist, 55, 68-78.

http://dx.doi.org/10.1037/0003-066X.55.1.68

Ryan, R. M., \& Deci, E. L. (2007). Active human nature: Self-determination theory and the promotion and maintenance of sport, exercise, and health. In M. S. Hagger \& N. L. D. Chatzisarantis (Eds.), Intrinsic motivation and self-determination in exercise and sport (pp. 1-19). Leeds, UK: Human Kinetics Europe.

Sallis, J.F., \& McKenzie, T.L. (1991). Physical education's role in public health. Research Quarterly for Exercise and Sport, 64, 25-31.

http://dx.doi.org/10.1080/02701367.1991.10608701

Satorra, A., \& Bentler, P. M. (1994). Corrections to test statistics and standard errors on covariance structure analysis. In A. V. Eye \& C. C. Clogg (Eds.), Latent variable analysis: Applications in developmental research (pp. 339-419). Thousand Oaks, CA, United States: Sage.

Skinner, E. A., \& Belmont, M. J. . (1993). Motivation in the classroom: Reciprocal effects of teacher behavior and student engagement across the school year. Journal of Educational Psychology, 85, 571-581.

http://dx.doi.org/10.1037/0022-0663.85.4.571

Skinner, E. A.; Furrer, C.; Marchand, G. , \& Kindermann, T. (2008). Engagement and disaffection in the classroom: Part of a larger motivational dynamic? Journal of Educational Psychology, 100, 765-781.

http://dx.doi.org/10.1037/a0012840

Skinner, E.A.; Kindermann, T.A., \& Furrer, C.J. (2009). A motivational perspective on engagement and disaffection: Conceptualization and assessment of children's behavioral and emotional participation in academic activities in the classroom. Educational and Psychological Measurement, 69, 493-525.

http://dx.doi.org/10.1177/0013164408323233

Standage, M.; Duda, J.L., \& Ntoumanis, N. (2003). A model of contextual motivation in physical education: Using constructs form self-determination and achievement goal theories to predict physical activity intentions. Journal of Educational Psychology, 95, 97-110. http://dx.doi.org/10.1037/0022-0663.95.1.97

Standage, M.; Duda, J.L., \& Ntoumanis, N. (2005). A test of Self-determination theory in school physical education. British Journal of Educational Psychology, 75, 411-433. http://dx.doi.org/10.1348/000709904X22359

Standage, M.; Duda, J.L., \& Ntoumanis, N. (2006). Students' motivational processes and their relationship to teacher ratings in school physical education: A self-determination theory approach. Research Quarterly for Exercise and Sport, 77, 100-110. http://dx.doi.org/10.1080/02701367.2006.10599336

Standage, M., \& Ryan, R.M. . (2012). Self-determination theory and exercise motivation: Facilitating self-regulatory processes to support and maintain healthy and well-being. In G. C. Roberts \& D. C. Treasure (Eds.), Advances in motivation in sport and exercise (3rd ed., pp. 233-270). Champaign, IL: Human Kinetics.

http://dx.doi.org/10.1093/oxfordhb/9780199731763.013.0012 
Taylor, I. M., \& Lonsdale, C. (2010). Cultural differences in the relationships among autonomy support, psychological need satisfaction, subjective vitality, and effort in British and Chinese physical education. Journal of Sport \& Exercise Psychology, 32, 655-673.

Taylor, I. M.; Ntoumanis, N.; Standage, M., \& Spray, C.M. (2010). Motivational predictors of physical education students' effort, exercise intentions, and leisure-time physical activity: A multilevel linear growth analysis. Journal of Sport \& Exercise Psychology, 32, 99-120.

Trost, S.G. (2007). Trends in sport and physical activity participation in Australian children and youth. Junior Sport Matters: Briefing Papers for Australian Junior Sport (pp. 7-13): Australian Sports Commission.

Trost, S.; Loprinzi, P.D.; Moore, R., \& Pfeiffer, K. (2011). Comparison of accelerometer cut points for predicting activity intensity in youth. Medicine and Science in Sports and Exercise (Special Communication), 1360-1368.

http://dx.doi.org/10.1249/MSS.0b013e318206476e

Wang, C. K. J.; Hagger, M., \& Liu, W. C. (2009). A cross-cultural validation of Perceived Locus of Causality Scale in physical education context. Research Quarterly for Exercise and Sport, 80, 313-325. http://dx.doi.org/10.1080/02701367.2009.10599566

Ward, J.; Wilkinson, C.; Graser, S.V., \& Prusak, K. A. (2008). Effects of Choice on Student Motivation and Physical Activity Behavior in Physical Education. Journal of Teaching in Physical Education, 27, 385-398.

Williams, G. C., \& Deci, E. L. (1996). Internalization of Biopsychosocial Values by Medical Students: A Test of Self-Determination Theory. Journal of Personality and Social Psychology, Vol 70, 767-779.

http://dx.doi.org/10.1037/0022-3514.70.4.767

Wolters, C.A. (2004). Advancing achievement goal theory: Using goal structures and goal orientations to predict students' motivation, cognition, and achievement. Journal of Educational Psychology, 96, 236-250.

http://dx.doi.org/10.1037/0022-0663.96.2.236

Wright, M.T.; Patterson, D.L., \& Cardinal, B.J. (2000). Increasing children's physical activity. Journal of Physical Education. Recreation \& Dance, 71, 26-29. http://dx.doi.org/10.1080/07303084.2000.10605981

Yli-Piipari, S.; Wang, C. K. J.; Jaakkola, T., \& Liukkonen, J. (2012). Examining the growth trajectories of physical education students' motivation, enjoyment, and physical activity: A person-oriented approach. Journal of Applied Sport Psychology, 24, 401417. 